\title{
LAND CAPABILITY STUDY AND MAP IN FUNCTION OF LAND \\ PROTECTION, SPATIAL PLANNING AND AGRO-ECOLOGICAL ZONING
}

Melisa LJUŠA ${ }^{1 *}$, Hamid ČUSTOVIĆ ${ }^{1}$, Mehmed CERO²

UDK 631.164(497.6)

\begin{abstract}
The main act to consider the value of land from the perspective of various sectors and their needs (urban planning, agriculture etc.) in the Federation of B\&H is the Decree on unique methodology for preparation of the spatial planning documents (Official Gazette of the Federation of B\&H, No. 63/04 and No. 50/07), which prescribes the obligation of making the Land capability study as a segment of spatial basis. Land capability study projects are being implemented by the Institute of Soil, Agro chemistry and Melioration (PAM) of the Faculty of Agricultural and Food Sciences University of Sarajevo. By using defined soil bonity categories, land capability study defines the natural potential of soils in terms of agricultural production and food production, and defines the zones for various land use types. From the rational land use point of view, it means adequate spatial planning, urban development and environmental protection. This paper aims to present the importance, characteristics as well as use of the Land capability study at the municipality level using municipalities of Tuzla Canton as example. Agricultural areas of on the territory of five municipalities in Tuzla Canton (Gradacac, Gracanica, Kalesija, Zivinice, Sapna) account for $44,356.1$ ha or $42.6 \%$ of the total area. Represented in these areas are soil bonity categories that range from II to VII. The first four bonity categories that are determined exclusively as agricultural land account for $28,739.91$ ha or $63.1 \%$ of the total area. Within this group, the most represented is the IVb category with $17,229.8$ ha. The best quality bonity categories II and III account for 7,514.3 ha or $16.5 \%$ of the total area. Analysis of the orthophoto images has identified a significant dynamics of change in space in the period 2008-2012 in four municipalities (Gradacac, Kalesija, Zivinice, Gracanica). Analysis has established that artificial areas (developed)

\footnotetext{
${ }^{1}$ Faculty of Agricultural and Food Sciences, University of Sarajevo, Zmaja od Bosne 8, 71000 Sarajevo, Bosnia and Hercegovina

${ }^{2}$ Federal Ministry of Environment and Tourism, Marka Maulića 2, 71000 Sarajevo, Bosnia and Hercegovina

*Corresponding author: melisa.ljusa@gmail.com
} 
increased by 737 ha, agricultural areas without orchards decreased by $1,136.72$ ha, while the areas under orchards increased by 283.13 ha. The largest expansion of developed areas and settlements was recorded within the bonity categories IVb $(47 \%$ of the total change) and III (27\%).

Keywords: land capability, land protection, spatial planning, agro-ecological zoning

\section{INTRODUCTION}

Change in land cover/land use in B\&H is very dynamic. According to the CORINE data in the period 2000-2012, total change amounted to $67,672.05$ ha of which $28.4 \%$ pertain to change within agricultural land. The most significant change is the conversion of agricultural land into artificial surfaces which accounts for 8,658.5 ha (Ljuša, 2015; Ljuša et al., 2015).

Spatial planning is a highly multidisciplinary task where within the process of defining real space we meet with: natural characteristics of the area (land, climate, morphology, etc.), economic (level of production, employment), social (population characteristics), technical (infrastructural systems) and super-structural systems (Bublin, 2000).

Spatial planning was introduced in $\mathrm{B} \& \mathrm{H}$ rather late. The first B\&H Spatial Plan 1981-2000 was adopted in 1982. Projections of this spatial plan required about 100,000 ha of land for construction. After the adoption of the B\&H Spatial Plan, municipality spatial plans were developed in a way which provided the protection of agricultural and forest land.

The basis for the adoption of municipal spatial plans were the land use value maps. According to available data, before September 1985 only four out of a hundred and five municipalities had the adopted spatial plan: Bugojno, Cazin, Lukavac and Mostar. On the other hand, the land use value maps being one of the main bases for the adoption of spatial and urban plans, were by that time either completed or in the phase of completion in fifty municipalities. For most municipalities that were significant in terms of agricultural production, these maps were not developed.

The lack of adequate policies and planning solutions are particularly evident in the recent history of $\mathrm{B} \& \mathrm{H}$, from 1992 to this day. The system of spatial planning has evolved in a different direction than expected. The reasons include numerous social and political, economic and cultural changes as well as the lack of a state level authority for spatial planning, given that the Constitution of B\&H does not address spatial planning and development as an explicit state jurisdiction. The situation is the same in the area of land policies.

Although the spatial planning activities in the entities are related to the laws governing this area, the existing legislation on spatial planning in general is not satisfactory and does not comply with the EU regulations. Namely, B\&H has to comply with EU principles of spatial planning contained in the European Commission's European Spatial 
Development Perspective-1999 (ESDP) and the guiding principles of the European Conference of Ministers responsible for Regional Planning-2000 (CEMAT) as well as other EU directives concerning spatial planning. When it comes to harmonization, in addition to lack of a state level ministry responsible for spatial planning, there is also a problem relating to the fact that spatial planning involves activities that are performed by other ministries (environment, transport, etc.) whose regulations also need to be harmonized with the EU. The problem is the lack of financial analyzes and linkage with the plans of economic and social development as well as the lack of criteria and indicators for monitoring and evaluating the implementation of spatial plans which is very important when it comes to trans-boundary areas (GAP, 2012).

In the Federation of $\mathrm{B} \& \mathrm{H}$ land use in the physical planning documents is determined based on the land use value maps. Decree on unique methodology for preparation of the spatial planning documents (Official Gazette of the Federation of B\&H, No. 63/04 and No. 50/07) prescribes the obligation of making the Land capability study as a segment of spatial basis. The land use value map exists in just a few municipalities in the Federation of B\&H.

Main objectives of this study are to prepare thematic databases and maps and to explore and analyze land resources of certain municipality by using Geographic Information System (GIS) and remote sensing source of information (ortho-photos). Based on this database, the further objective is to determine the distribution of different land use types, as well as to perform valorization of soil through its quality (bonity) categories and analysis of pedological characteristics of the present soil types. The adoption of the Law on agricultural land (Official Gazette of the Federation of B\&H, No. 52/09) and the Instruction on professional criteria for the classification of land into bonity categories (Official Gazette of the Federation of B\&H, No. 78/09) has protected the most valuable agricultural land used for food production from other consumers. According to these regulations, the areas of agricultural land could not be reduced or used for nonagricultural purposes until the adoption of spatial and urban plans.

\section{MATERIAL AND METHODS}

This paper aims to present the importance, characteristics as well as use of the Land capability study at the municipality level in Tuzla Canton. To analyze the presented data we used the Studies on land use value for the following municipalities: Gradacac, Gracanica, Kalesija, Zivinice and Sapna.

Land quality evaluation is used to determine the level of its suitability for agricultural production based on the scoring of natural conditions for crop production (soil, climate, relief). Land quality evaluation is performed by awarding points to the land rating properties in the way that the highest-quality land of the I rating category is awarded 100 points and the lowest quality land of the VIII rating category 10 points. Land quality rating is calculated using the following formula: 


$$
\mathrm{B}=\sqrt{\operatorname{Tx} \mathbf{K x} \mathbf{K x} \mathbf{R x}\left(1-\frac{\sum \% \text { posebni efekti }}{\mathbf{1 0 0}}\right)}
$$

B-bonity score; T-soil properties score; K-climate properties score; R-relief properties score; $\sum \%$ special effects (posebni efekti)

Soil bonity categories are identified in accordance with the Law on Agricultural Land and based on field research and laboratory tests of soil samples taken from the field as follows:

- Land classified as I to IV cadastral, i.e. bonity category shall be determined solely as agricultural land;

- Land classified as V and VI cadastral, i.e. bonity category shall be determined as agricultural and exceptionally as land for other purposes;

- Land classified as VII and VIII cadastral, i.e. bonity category shall be determined as land that will be used for other purposes as required.

On the basis of orthophoto images an analysis of the existing use value of the land and spatial dispersion of agricultural, forest and barren land as well as water surfaces was made. The analysis of orthophoto images from 2008. and 2012. established the dynamics of change in space, i.e. land cover and land use, and associated it with the bonity categories.

Agro-ecological zoning i.e. assessment of suitability for the cultivation of individual crops is determined based on the FAO agro-ecological zones methodology.

\section{RESULTS AND DISCUSSION}

Tuzla Canton comprising 13 municipalities is located in the north-eastern part of B\&H . Total area of the Canton amounts to $2,730 \mathrm{~km}^{2}$ which accounts for $5.3 \%$ of the total area of B\&H. Area of the five studied municipalities (Gradacac, Kalesija, Zivinice, Gracanica, Sapna) amounts to $104,225.42$ ha or $1,042.25 \mathrm{~km}^{2}$, which is $38.2 \%$ of the total area of the Canton.

When it comes to the land bonity (rating) categories, the most represented category in these five municipalities is $\operatorname{IVb}(17,229.83 \mathrm{ha})$, whereas the least represented is VII bonity category ( $225.85 \mathrm{ha}$ ) (Table 1 , Figure 1$)$. The best rating categories II and III account for 604.35 ha and 6,909.91 ha respectively. The largest areas of the II bonity category were identified in the municipality of Gradacac, amounting to 376.79 ha, while the smallest ones were recorded in Gracanica ( $5.53 \mathrm{ha}$ ). As for the III bonity category, the largest areas were identified in Kalesija (3,369.57 ha) and the smallest in Sapna (7.4 ha). As an illustration, Sarajevo Canton (surface $1,276.9 \mathrm{~km}^{2}, 9$ municipalities) has only 3,159 ha of agricultural land of the I-III bonity categories (Čustović et al., 2015). IVa bonity category is most represented in Zivinice (2,518.90 ha), and least represented in 
Gradacac (190.9 ha). On the other hand, Gradacac has the largest area of the IVb ctegory (6870. ha), and Gracanica of the V (3,635.64 ha) and VI (2,349.17 ha) bonity categories. The VII bonity category has been identified in the area of Zivinice (143.2 ha) and Gracanica (82.65 ha).

Table 1. Overview of land bonity categories in the selected municipalities of Tuzla Canton

\begin{tabular}{crrrrrrrr}
\hline $\begin{array}{c}\text { Bonity } \\
\text { categories }\end{array}$ & Score & Gradacac & Kalesija & Zivinice & Gracanica & Sapna & Total & \% \\
\hline \hline II & $80-90$ & 376.79 & 63.63 & 122.8 & 5.53 & 35.6 & $\mathbf{6 0 4 . 3 5}$ & $\mathbf{1 . 3}$ \\
\hline III & $60-80$ & $1,629.66$ & $3,369.57$ & $1,234.40$ & 668.88 & 7.4 & $\mathbf{6 , 9 0 9 . 9 1}$ & $\mathbf{1 5 . 2}$ \\
\hline IVa & $40-60$ & 190.9 & 349.87 & $2,518.90$ & 445.55 & 490.6 & $\mathbf{3 , 9 9 5 . 8 2}$ & $\mathbf{8 . 8}$ \\
\hline IVb & $40-60$ & $6,870.2$ & $3,437.37$ & $2,647.80$ & $2,737.56$ & $1,536.90$ & $\mathbf{1 7 , 2 2 9 . 8 3}$ & $\mathbf{3 7 . 8}$ \\
\hline V & $30-40$ & $2,345.14$ & $2,185.66$ & $1,526.50$ & $3,635.64$ & $1,126.70$ & $\mathbf{1 0 , 8 1 9 . 6 4}$ & $\mathbf{2 3 . 8}$ \\
\hline VI & $20-30$ & $1,322.01$ & 859.29 & $1,179.20$ & $2,349.17$ & 38.1 & $\mathbf{5 , 7 4 7 . 7 7}$ & $\mathbf{1 2 . 6}$ \\
\hline VII & $10-20$ & 0 & 0 & 143.2 & 82.65 & 0 & $\mathbf{2 2 5 . 8 5}$ & $\mathbf{0 . 5}$ \\
\hline
\end{tabular}

Source: Faculty of Agricultural and Food Sciences, PAM Institute, 2015
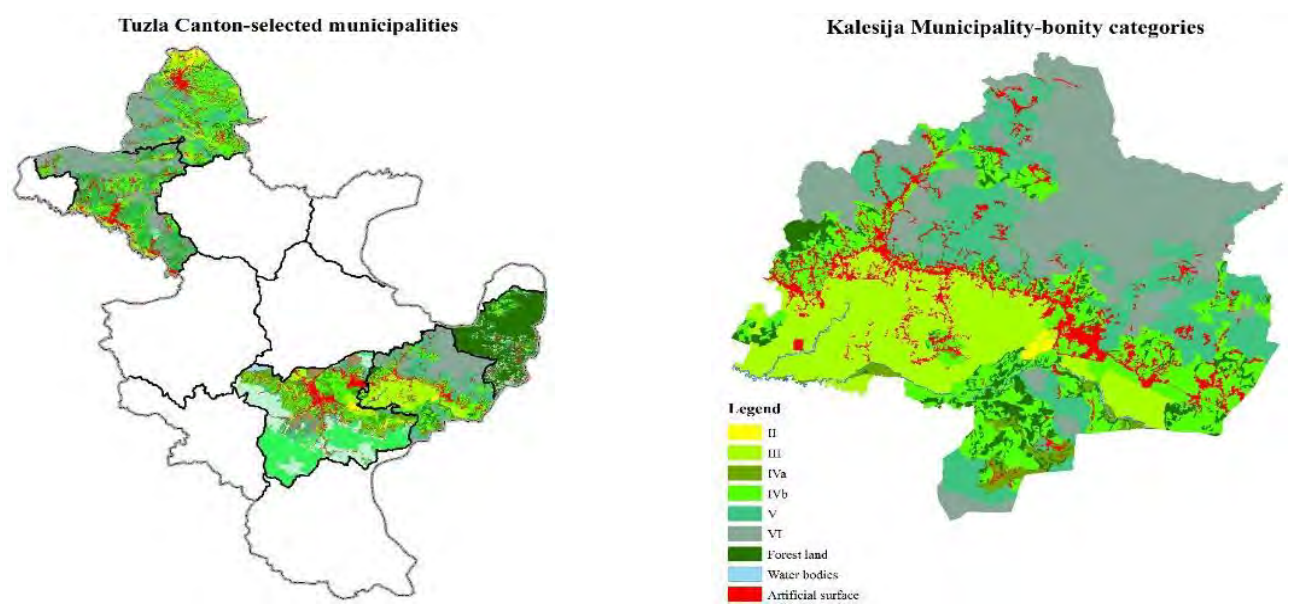

Figure 1. Bonity categories-example of Kalesija municipality

The Republic of Croatia also uses the land bonity system that is determined based on the value (bonity) of soil, climate and relief characteristics and other corrective factors such as rockiness, stoniness, floods and the like, according to the formula $B=\sqrt{T x K x R}$, where $\mathrm{B}$ 
stands for bonity of land without corrections, T-for bonity score of the soil; K-for bonity score of climate and R-for bonity score of relief (Kovačević, 1992; Bogunović, 2009).

According to Kovačević, thus defined bonity indicates versatile possibilities for land use, while the land quality evaluation method along with the determination of the economic conditions of agricultural production could replace the previous method of land classification and serve as a basis of the value of land in land consolidation assessment.

The analysis of land cover/land use, based on orthophoto images from 2012, has identified seven major categories of coverage (Table 2). The results of the analysis show that the largest areas in these five investigated municipalities are covered by the category of forest vegetation and other natural surfaces which account for $45,104.32$ or $43.3 \%$ of the total area of the subject municipalities. The second most represented category is agricultural land without orchards which accounts for $41,530.58$ ha (39.8\%). Orchards occupy an area of $2,825.56$ hectares so it can be stated that the total agricultural area accounts for $42.5 \%$ of the total area. Artificial surfaces, water bodies and quarries/mines account for $10.4 \%$ of the total area. Succession comes rather high on the list when it comes to the coverage and it covers an area of about 3,895 hectares or $3.7 \%$ of the total area.

The area of agricultural land ranges from 9,336 ha (Zivinice) to 9,895.11 ha recorded in Gradacac. The exception is the municipality of Sapna which has a total of 3.142,5 hectares of agricultural land, which is understandable considering that the total area of the municipality is two times smaller than the other municipalities. The municipality of Gradacac significantly excels when it comes to the area under orchards which amounts to $2,084.85$ ha.

Table 2. Overview of the land cover/land use in the selected municipalities of Tuzla Canton (2012)

\begin{tabular}{|c|c|c|c|c|c|c|}
\hline Category & Gradacac & Kalesija & Zivinice & Gracanica & Sapna & Total \\
\hline Artificial surfaces & $1,949.30$ & $1,469.83$ & $3,026.70$ & $1,943.74$ & 348.9 & $8,738.47$ \\
\hline $\begin{array}{l}\text { Agricultural land } \\
\text { without orchards }\end{array}$ & $9,895.11$ & $9,726.80$ & $9,336.00$ & $9,427.17$ & $3,145.50$ & $41,530.58$ \\
\hline Orchards & $2,084.85$ & 116.09 & 36.9 & 497.82 & 89.9 & $2,825.56$ \\
\hline $\begin{array}{l}\text { Forest vegetation } \\
\text { and other natural } \\
\text { surfaces }\end{array}$ & $6,860.56$ & $7,301.34$ & $14,095.80$ & $8,964.62$ & $7,882.00$ & $45,104.32$ \\
\hline Succession & 754.37 & $1,078.06$ & 715 & 619.27 & 727.8 & $3,894.50$ \\
\hline Water surfaces & 73.27 & 79.07 & 711.6 & 51.83 & 40.1 & 955.87 \\
\hline Quarries/mines & 0 & 7.36 & $1,140.7$ & 28.07 & 0 & $1,176.13$ \\
\hline Total & $21,617.45$ & $19,778.55$ & $29,062.70$ & $21,532.52$ & $12,234.2$ & $104,225.42$ \\
\hline
\end{tabular}

Source: Faculty of Agricultural and Food Sciences, PAM Institute, 2015 
Analysis of changes in coverage in the period 2008-2012 shows that in four municipalities (Gradacac, Kalesija, Zivinice, Gracanica) artificial surfaces (developed land) have increased by 737 ha, agricultural land without orchards have decreased by 1,136.72 ha, while the areas under orchards have increased by 283.13 ha (Figure 2).

The biggest increase of the category of artificial surfaces was identified in the municipality of Zivinice amounting to 363.9 ha. Analyzes indicate a significant reduction of agricultural land without orchards (333 ha), therefore it can be stated that these surfaces have been converted into artificial surfaces (Figure 1). Succession is recorded in an area of $97.3 \mathrm{ha}$.

The situation in the municipality of Kalesija is significantly different. Namely, artificial surfaces have increased by 183 ha, while agricultural areas without orchards have reduced by slightly over 513 ha. However, in the context of the change there is an increase in the areas under orchards amounting to 5.14 ha as well as a significant occurrence of succession of agricultural areas amounting to $374.18 \mathrm{ha}$. This is an indication of a serious problem of abandonment of rural areas and agricultural activities.

In the municipality of Gracanica, artificial surfaces have increased by 115.48 ha, whereas agricultural areas have reduced by $271.13 \mathrm{ha}$. However, there is a large increase in areas under orchards of 165.55 ha which indicates the intensification of agricultural production in this fruit production region. The municipality of Gradacac has experienced the smallest increase in artificial surfaces amounting to $74.61 \mathrm{ha}$. It also recorded the least reduction in agricultural areas amounting to approximately 19 ha. Gradacac, just like Gracanica had a significant increase in orchards by 117.54 ha.
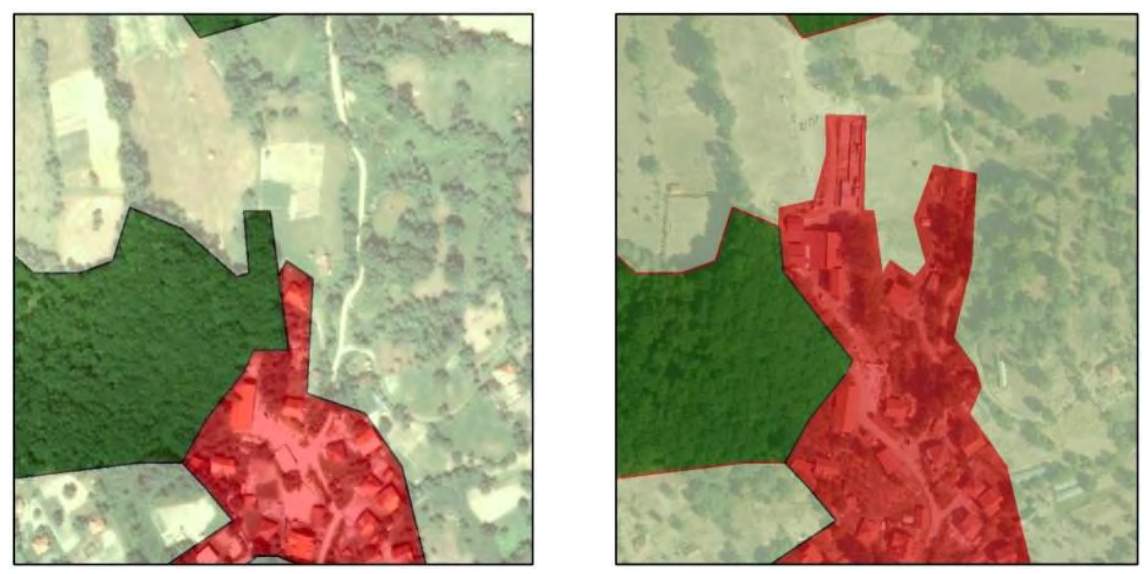

Figure 2. State of land cover (2008) and the increase in artificial surfaces (2012) Source: Faculty of Agricultural and Food Sciences, PAM Institute, 2015 
In view of these changes the question of identifying what bonity categories were affected by the expansion of developed or artificial areas has been raised. To answer to this question, we used the municipality of Kalesija as an example (Chart 1). The analysis shows that the largest expansion of developed surfaces and settlements occurred within the bonity category IVb ( $47 \%$ of total change). However, there is a rather worrying information that exceptional and valuable agricultural land of the III bonity category (soils on flat relief and slope up to $3 \%$ in the plains, or up to $16 \%$ on hilly terrain, medium deep or deep soils with depth over $60 \mathrm{~cm}$, with a humus-accumulative horizon over $30 \mathrm{~cm}$ deep, $\mathrm{pH}$ reaction $6-8,5$ etc.) for which the law provides that they must be protected against use for non-agricultural purposes, was to a large extent used for the expansion of artificial surfaces (27\%). A significant expansion of artificial surfaces was also recorded in the area of $\mathrm{V}$ bonity category.

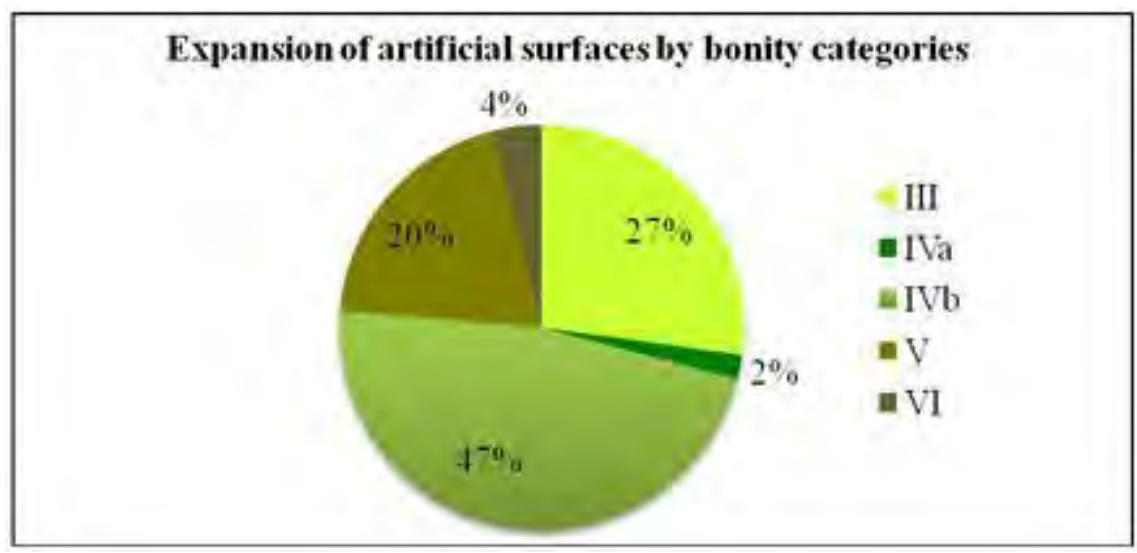

Chart 1. Expansion of artificial surfaces by bonity categories in the municipality of Kalesija

\section{CONCLUSIONS}

„Spatial planning is critical for delivering economic, social and environmental benefits by creating more stable and predictable conditions for investment and development, by securing community benefits from development, and by promoting prudent use of land and natural resources for development. Spatial planning is thus an important lever for promoting sustainable development and improving quality of life" (UN, 2008).

The presented data show a significant dynamics in land use which considerably differs from one municipality to another. There is an evident pressure on agricultural land in terms of its use for construction. A significant reduction in the highest quality agricultural land over a period of just four years suggests that there is a large discrepancy 
between the spatial planning and the protection of agricultural land from being used for non-agricultural purposes (Ljuša, 2015).

Data on the number of spatial and urban plans in the municipalities of the Federation of $\mathrm{B} \& \mathrm{H}$ are not accessible to the public, which speaks for itself when it comes to their existence, obsolescence and compliance with other spatial planning documents (NAP, 2014). On the other hand, a few municipalities have the land use value maps.

Given the current situation regarding the lack of basis for spatial planning, we can rightfully ask how a municipality or any other administrative level in general can even begin the process of spatial planning without not only the updated layouts but also the basis of the quality of the land necessary for making adequate decision on the use of certain land area. There is also the question of land evaluation methods performed without adequate bonity layouts, in the context of determining its price in the process of conversion. According to Čustović et al. (2013a) the lack of analyses of bonity categories, information on land quality and spatial maps, give enough room for speculations and manipulations concerning this resource.

One of the consequences of the above stated problems and shortcomings is illegal construction. Facilities are first built without permits and then legalized. Massive illegal construction testifies to a failure to develop a coherent and comprehensive urban planning and zoning policy (Tsenkova, 2005). As stated by Čustović and Bajramović (2005), monitoring of illegal change of use of agricultural land and its actual use is very scarce, penalties are generally uncollectible, and municipalities and cantons do not have the capacity to fully implement the legal provisions.

However, despite the fact that agricultural land is being destructed, new buildings are literally scattered across the area which prevents rational equipping of such neighborhoods with infra- and super-structure. The key consequence of illegal construction and/or bad planning is a change of economic, environmental or aesthetic value of the landscape which is almost never discussed in B\&H, though we are all well aware of it.

Yet, something that should be particularly insisted upon in $\mathrm{B} \& \mathrm{H}$ is the distinction between urban and rural space, considering the need of rural areas to be planned consistent with lifestyle, as well as the evaluation of the landscape which is particularly important to us as B\&H is a rural country (Ljuša, 2015).

The significance of the landscape is especially pointed out in the European Landscape Convention (ratified by $\mathrm{B} \& \mathrm{H}$ ) which, among other things, states that each party (signatory) undertakes "to incorporate landscape in their regional and urban planning policies and in policies relating to culture, environmental protection, agriculture, social, 
economic and any other policies which could directly or indirectly affect landscape". In this regard, we must not forget the abandoned rural areas and land which results in loss of biodiversity, degradation of ecosystems in general and the destruction of natural and cultural heritage (Čustović et al., 2013b).

The issue of adequate planning and management of the landscape is reflected in the fact that all the programs of rural development, according to the new EU agricultural policy, must include measures to protect and preserve the landscape in rural areas. The aspect of landscaping and the protection of land and natural resources within it, is definitely an issue which has to be included in the rural development strategies at all levels.

The use of land for non-agricultural purposes is not a problem exclusive to B\&H. For example, in Germany in the period 1998-2000, the use of land for non-agricultural purposes accounted for $131 \mathrm{ha} /$ day; later on there was a slight decrease but in 2004 it moved back to 131 ha per day (Progress Report on the 2012 National Sustainable Development Strategy). Change of land use particularly affected rural areas and about $50 \%$ of land was turned into concrete (soil sealing) (Loehr, 2012). One of the pilot measures to reduce the areas intended for construction which is undertaken in municipalities across Germany is urban permit trading. Each municipality has certain number of certificates which determine the area for construction. If the amount of open space on which the municipality wants to build exceeds the amount of open space provided by their certificates, the municipality can purchase additional certificates from other municipalities. Potential buyers of certificates tend to be economically growing municipalities that want to strengthen their growing economy. Examples of good practice such as this measure can be of great help in the development of measures, policies and specific projects at municipal level in B\&H whose funding could be provided by EU funds.

One of the basis for spatial planning in the Federation of B\&H is the development of land use value map which along with the supporting GIS database provides the spatial distribution and representation of land, which allows observation and commitment of a large land area to various purposes based on its status and environmental conditions. This is especially important in view of making decisions as to what land and parts of space can be excluded from their primary function and use them for other purposes. On the other hand, GIS provides the possibility of continuous updating, i.e. monitoring the changes in space, analysis and application of various models with the aim of assessing the use of an area.

One such approach is the agro-ecological zoning which, among other things, point to phenomena that are typical of land types or possible difficulties that are likely to be 
expected from the perspective of cultivation of some crop (Figure 3). This type of assessment and analysis facilitates the definition and implementation of measures aimed at mitigating or completely eliminating certain limitations and phenomena or possibly giving up on certain plans in the event that measures are not technically and economically justified. This approach allows for farmers who want to invest to be more objective while analyzing what type of the production to select or whether to apply certain agricultural practices which could improve soil condition and make it more suitable for a particular crop (Figure 4).

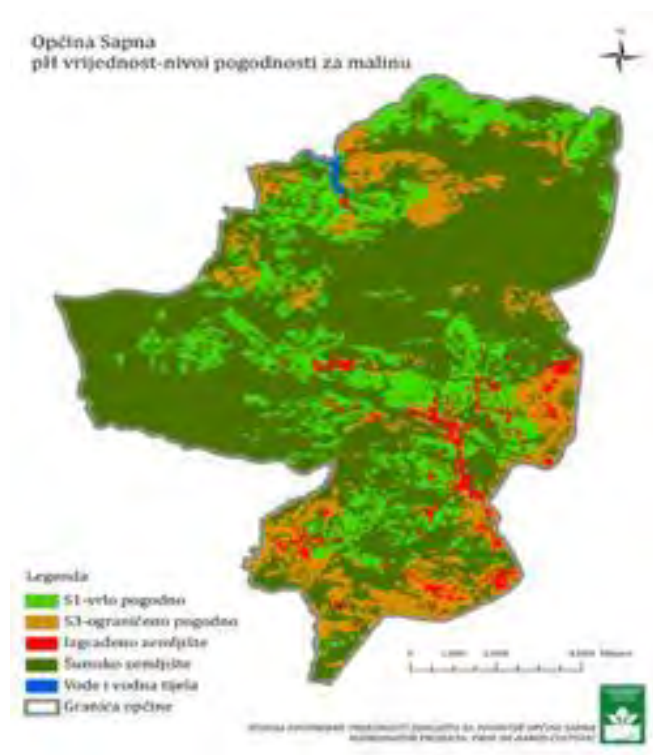

Image 3. pH-level of suitability for growing raspberries

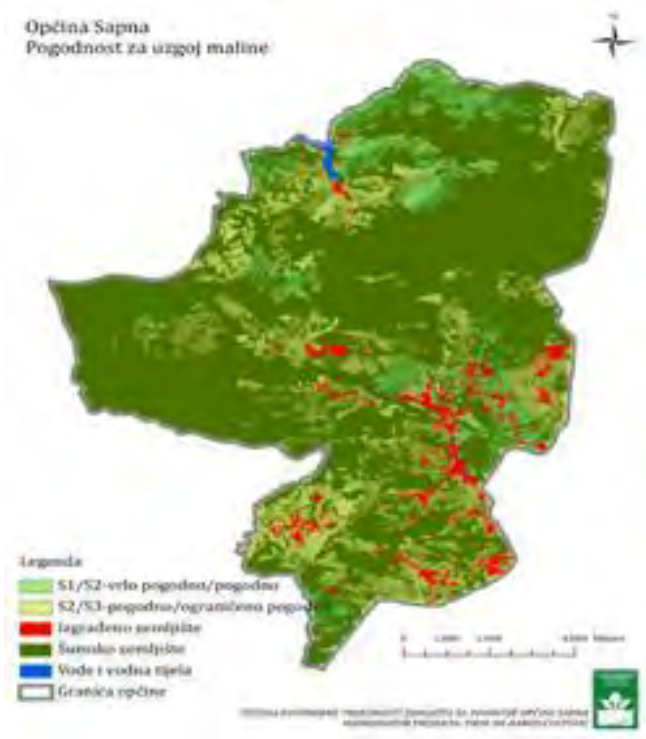

Image 4. Suitability of soil for growing raspberries from the point of $\mathrm{pH}$, humus, $\mathrm{CaCO}_{3}$ and texture

\section{REFERENCES}

Bogunović Matko. 2009. Vrjednovanje zemljišta i racionalno koristenje prostora. Agronomski fakultet Sveučilišta u Zagrebu.

Bublin M. 2000. Prostorno planiranje. Univerzitetska knjiga, Studentska štamparija Univerziteta. Sarajevo.

Čustović H., Bajramović S. 2005. Državno zemljište kao potencijalni činilac poboljšanja posjedovne strukture u BiH. Uvodni referat na 32. Sajmu šljive, Gradačac. 
Čustović H., Kovačević Z., Tvica M. 2013b. Ruralna ekologija. Sarajevo: Poljoprivredno-prehrambeni fakultet Univerziteta u Sarajevu.

Čustović H., Ljuša M., Marković M. 2013a. Land use changes and loss of soil in Bosnia and Herzegovina as consequences of the war and socio-economic transition, $2^{\text {nd }}$ Scientific Conference UNCCD, Zbornik radova, 190-194.

Čustović H., Ljuša M., Taletović J., Tvica M. 2015. Application of land categorization in spatial planning of urban and suburban areas of Sarajevo. Növénytermelés (Crop production), Vol. 64, 131-135.

GAP. 2012. Politika u oblasti prostornog planiranja, Projekat upravne odgovornosti.

GEF i UNEP. 2014. Državni akcioni program za borbu protiv degradacije zemljišta i ublažavanja posljedica suše u BiH (NAP BiH). Sarajevo.

Izvještaj o napretku Nacionalne strategije održivog razvoja za 2012. godinu. Njemačka federalna vlada.

Kovačević P. 1992. Agronomski glasnik 4/1992. Pregledni članak. ISSN 0002-1954 UDK 631.61

Ljuša M., Cero M., Čustović H. 2015. Promjena namjene poljoprivrednog zemljišta i funkcija tla u Bosni i Hercegovini u periodu 2000-2012. godina. Radovi Poljoprivredno-prehrambenog fakulteta, Univerziteta u Sarajevu, God. LX, broj 65/1, 7-16.

Ljuša Melisa. 2015. Trendovi i karakteristike promjena načina korištenja poljoprivrednog zemljišta u Bosni i Hercegovini. Disertacija. Poljoprivredno-prehrambeni fakultet Univerziteta u Sarajevu.

Loehr D. 2012. The Role of Tradable Planning Permits in Environmental Land Use Planning: A Stocktake of the German Discussion. Chapter 10.

Studija upotrebne vrijednosti zemljišta za područje općine Gračanica. Poljoprivrednoprehrambeni fakultet Univerziteta u Sarajevu. Sarajevo, 2013.

Studija upotrebne vrijednosti zemljišta za područje općine Gradačac. Poljoprivrednoprehrambeni fakultet Univerziteta u Sarajevu. Sarajevo, 2013.

Studija upotrebne vrijednosti zemljišta za područje općine Kalesija. Poljoprivrednoprehrambeni fakultet Univerziteta u Sarajevu. Sarajevo, 2014.

Studija upotrebne vrijednosti zemljišta za područje općine Sapna. Poljoprivrednoprehrambeni fakultet Univerziteta u Sarajevu. Sarajevo, 2015.

Studija upotrebne vrijednosti zemljišta za područje općine Živinice. Poljoprivrednoprehrambeni fakultet Univerziteta u Sarajevu. Sarajevo, 2014.

Tsenkova, S. 2005. Trends and Progress in Housing Reforms in South-Eastern Europe. Council of Europe Development Bank, Paris.

UN. 2008. Spatial Planning: Key Instrument for Development and Effective Governance with Special Reference to Countries in Transition. New York and Geneva. 